tive narrow adaptability are better suited for intensive management while clones with broad adaptability are desired for forest stand conditions. The fast starter clones will be especially useful for very short rotation management. Production trials are needed to test the suitability of various clones for various management systems. However, the problem of clonal selection is not the only one on which the success of the operation depends.

In the management of such an intolerant and demanding tree as hybrid poplar, one must have the right soil conditions and control competitive weeds. In production trials in southeastern Ontario, we have used mechanical site preparation, soil cultivation and herbicides.

Before the hybrid poplar program becomes fully operational many other aspects in addition to clonal selection and site control will have to be worked out, e.g., type of planting stock, spacing, harvesting techniques and coppice regeneration. The mechanization of planting, tending and harvesting is also necessary. The outstanding potential of hybrid poplar clones makes the solution of these problems a challenge.

\section{Conclusions}

This brief presentation of the problem of hybrid poplar clonal selection and management has demonstrated that:

close co-operation of tree breeders and forest managers is needed for the selection of suitable clones and to learn how to manage them; the selection must be based on several years of observations in clonal tests replicated by site; specific clones are needed for specific sites, rotations and management systems.

\section{References}

Heimburger, C. 1968. Poplar breeding in Canada. In: Maini, J. S. and J. H. Cayford, Eds., Growth and utilization of poplars in Canada. Can. Dep. For. Rural Develop., For. Br., Publ. 1205. pp 88-100.

Hubbes, M. 1969. Benzoic and salicylic acids isolated from a glycoside of aspen bark and their effect on Hypoxylon pruinatum. Can. J. Bot. 47(8):1295-1302.

Zsuffa, L. 1973. Hybrid poplar pulpwood production trials in southeastern Ontario. For. Chron. 49(3):125.

Zsuffa, L. and H. Anderson. 1974. New culture and utilization concepts show promise. Poplar Council North Amer. News, Fall. 1974:4-5.

Zufa, L. 1969a. Poplar breeding in Canada. For. Chron. 45(6): $402-408$.

Zufa, L. 1969b. The heritability of the stem form of black poplar (Populus nigra L.). 2nd World Consultation Forest Tree Breeding, Washington, Aug. 7-16, 1969. FAO/FTB-693/7. 11 pp. (mimeo).

Zufa, L. and N. Zivanov. 1966. Indicators of a significant and specific correlation between the poplar clones and soil types. Sumarski list 90 (1-2):137-148 (in Yugoslav, with French summary).

\title{
Tree Improvement - A Company Viewpoint
}

\section{H. JENSEN}

Project Forester,

Tahsis Co. Ltd.,

Gold River, B.C.

The trend in British Columbia is towards intensive management. Since the application of tree improvement principles is essential to intensive management, the major B.C. companies with large timber holdings or Tree Farm Licenses have started their own tree improvement programs, particularly in the intensively-managed coastal forests.

At the beginning, it was recognized that cooperation between industry. government, and university was essential. Thus, the 'Plus Tree Board' was formed in 1959. This board set the quidelines and promoted the selection of Douglasfir (Pseudotsuga menziesii (Mirb.) Franco plus trees. The Plus Tree Board was later renamed 'The Tree Improvement Board' and the objectives were expanded to cover all aspects of tree improvement.

General meetings are held once a year and workshops conducted as needed. Recently, workshops have been held in seed orchard management and in the selection of hemlock plus trees. This year, sub-committees are working on a review of seed zones for the Vancouver Forest
District, locating suitable land for seed orchards, and the preparation of a proposal for a co-operative industrial tree improvement agency.

The industrial members of this board are B.C. Forest Products Ltd., Canadian Forest Products Ltd., Crown Zellerbach Co. Ltd., MacMillan Bloedel Co. Ltd., Pacific Logging Co. Ltd., Rayonier Co. Ltd., Tahsis Co. Ltd., and Weldwood Co. Ltd. All of them have embarked on tree improvement programs of varying scope and size. Co-operative projects have been undertaken and funded by these companies. Some of the projects are plus tree selections of Douglas-fir, western hemlock (Tsuga heterophylla (Raf.) Sarg. and Sitka spruce (Picea sitchensis (Bong.) Carr.; phenological studies of Douglas-fir; studies of grafting techniques; and assessment of scion-rootstock incompatibility of grafted Douglas-fir selections.

Most of the industrial members are committed to the selection and preservation of superior trees as base breeding populations and the development of first-generation orchards to meet current reforestation seed needs. Gains of 10 to $15 \%$ or more are expected from these orchards.

I have worked with the Tahsis Co. for 10 years; a company which has a firm belief in the value of genetics in forestry. Primarily through 
the efforts of Mr. Sven Rasmussen, our Chief Forester, the company has put considerable effort and money into the improvement of Douglasfir, western hemlock, and Sitka spruce. In addition to improving the genetic quality of these three species, the program will supply improved seed for artificial reforestation in the near future. Our steps for improvement are four: selection of superior phenotypes (plus trees); preservation of these phenotypes in clone banks; establishment of first-generation orchards; and controlled mating, progeny testing and reselection for second-generation orchards.

As the B.C. Forest Service has undertaken progeny testing and further breeding on a province-wide basis, our future involvement will be to co-operate in making controlled crosses and to supply the required test sites.

When our Douglas-fir program started in 1959, the Tahsis holdings were divided into three seed zones. The first was high elevation (above $1500 \mathrm{ft}$ ), low elevation coastal, and low elevation inland. The 220 plus trees in our program originated from these areas which were comparable to one of the three seed zones. The origin of all selections is recorded and then the material is put into the appropriate clone bank or seed orchard.

Grafted clone banks are established for the preservation of plus tree genotypes, phenological studies, cone production for progeny testing, and for the artificial regeneration program. Nine clone banks covering 42 acres with approximately 2,200 ramets have been established. Controlled crosses were made in these clone banks in 1966 and 1968 to obtain progeny for testing. Since 1968, cone production has been insignificant.

A separate seed orchard is established for each seed zone. Originally only grafted clonal orchards were set out. Due to incompatibility problems between scion and rootstock, mortality of up to $50 \%$ was expected. Thus, part of one orchard was filled with full-sib plus tree seedlings. This orchard now consists of a grafted clonal section, a mixed clonal and seedling section, and a full-sib seedling section. A total of four clonal orchards have been established on 22.7 acres with 7,700 ramets of 199 plus trees. One seedling orchard is 5.4 acres in size.

To ensure sufficient genetic variation in the orchards, 45 to 60 plus trees representing 15 to 20 good stands is considered ideal. The smallest orchard we have has 36 plus trees from 18 stands.

The first orchards established were located in the Upper Gold River Valley. As few natural Douglas-fir were in the area, pollen contamination in the orchard could be kept to a minimum. But, due to infrequent cone crops in this area, a new orchard was established in 1968 in the Saanich Peninsula, 225 miles south of Gold River. The climate in this area is ideal for cone production. In 1974, 11 bushels of cones were produced. Contamination in this new orchard will be minimized by mass pollination with the desired pollen.

Seven progeny tests have been planted to assess the plus trees and to rank them according to survival, volume growth, form and vigour of their offspring. The tests will also provide material for reselection and further breeding.

We plant 1,000,000 Douglas-fir seedlings annually and expect that the orchards will supply all of our seed requirements by 1980 .

In the hemlock program, we have selected 93 plus trees since 1963. An additional 84 trees from other co-operators are included in our program. The material has been vegetatively propagated by grafting of scions and rooting of cuttings.

The clone bank was started in 1970. As of April 1975, 96 clones were represented by 478 grafts and 298 cuttings. Numbers per clone vary from 1 to 35 individuals. This clone bank will also serve as an orchard and will be enlarged to include as many trees as possible.

A seedling seed orchard was established at Gold River in 1969 and expanded in 1970. A total of 1,100 trees of 35 half-sib families were planted. In 1976, the orchard will be modified and filled by planting 2-year-old container grown seedlings of 50 half-sib families.

Half-sib progeny tests were started in order to assess sample trees for further testing and for inclusion of the selections into the secondgeneration orchard. All progenies will be tested on three sites using a minimum of 100 seedlings per site. Two tests have already been planted in the Upper Gold River Valley. An estimated 900,000 trees per year will be planted over the next 15 years.

As local stands of Sitka spruce were being logged very rapidly in 1969 , an improvement program was started to preserve the local phenotypes and to supply seed for future plantings. Plus trees were selected on the Tahsis Tree Farm, on adjacent lands, and also on the northwestern part of Vancouver Island. A total of 160 trees are now in the program including 32 selected by Rayonier Ltd. A clone bank is being established at Gold River to preserve 5 ramets of each plus tree. It now includes 407 ramets of 105 clones.

The seed orchard is located at Saanich, adjacent to the Douglas-fir seed orchard. It will contain 15 ramets of 120 plus trees at a $10 \mathrm{ft} \times 10$ $\mathrm{ft}$ spacing. These trees will be reduced by thinning to 450 trees at a $20 \mathrm{ft} \times 20 \mathrm{ft}$ spacing. Presently the orchard contains 838 ramets of 107 clones. The first cone crop in this orchard was produced in 1974 and yielded two-thirds of a bushel of cones on the 4-year-old ramets. Approximately 200,000 seedlings will be planted annually during the next 15 years. The orchard should be able to supply the full requirements by 1980 .

In closing, I would like to emphasize that tree improvement is a valuable tool in intensive forest management. It is a long term investment and must be started 5 to 10 years before benefits can be reaped. A publicized tree improvement program is also a good way to let everyone know that the company is in the business of good longterm forest management. 